\title{
Pesquisa em educação, movimentos sociais e colonialidade: continuando um debate'
}

Edla Eggert"

\section{Resumo}

Este é um ensaio com base num artigo publicado na revista Educação e Pesquisa dos autores Danilo Streck e Telmo Adams, Pesquisa em educação: os movimentos sociais e a reconstrução epistemológica num contexto de colonialidade (2012). Segundo esses autores, para que seja coerente, essa epistemologia deve desconstruir a colonialidade com a qual somos marcados ao longo dos séculos da nossa existência. Neste ensaio, retomam-se alguns desses argumentos trazidos por Streck e Adams e pisa-se nesse chão da descolonialidade epistemológica, muito devagarinho. Argumenta-se que há uma mistura paradoxal nas propostas de pesquisa participante, educação popular, bem como dos movimentos de descolonização: a mistura da cópia que já somos, da antropofagia que fizemos com o que nos impuseram. A ideia da cópia e da repetição são apresentadas como numa experiência de artífice: a ação de fazer e refazer faz acontecer a obra e, portanto, produz também a aprendizagem. A tentativa é pensar modos singulares de buscar/produzir/criar conhecimento na perspectiva da educação latino-americana.

\section{Palavras-chave}

Colonialidade - Cópia - Recriação - Pesquisa participante Educação popular.

\footnotetext{
I- This article was originally presented at the 35th Meeting of the National Association of Post-Graduation and Research in Education (ANPED), held in Porto de Galinhas - its presentation was then supported by the Coordination for the Improvement of Higher Education Personnel (CAPES - PROEX). The article refers to my three current research projects, which are supported by the National Council for Scientific and Technological Development (CNPq).

II-Universidade do Vale do Rio dos Sinos, São Leopoldo, RS, Brasil.

Contact: edla.eggert@gmail.com
} 


\section{Research in education, social movements, and coloniality: continuing a debatel}

Edla Eggert"

I- Esse artigo foi, primeiramente, um trabalho apresentado na 35. ${ }^{\text {a }}$ Reunião da Associação Nacional de Pós-Graduação e Pesquisa em Educação (ANPEd), realizada em Porto de Galinhas, e teve apoio de Coordenação de Aperfeiçoamento do Pessoal de Nível Superior (CAPES - PROEX) para que o trabalho pudesse ser apresentado. 0 artigo remete aos meus três atuais projetos de pesquisa que contam com o financiamento do Conselho Nacional de Desenvolvimento Científico e Tecnológico (CNPq).

Il-Universidade do Vale do Rio dos Sinos, São Leopoldo, RS, Brasil.

Contato: edla.eggert@gmail.com

\section{Abstract}

This is an essay based on an article published in Educação e Pesquisa, by Danilo Streck and Telmo Adams, titled Pesquisa em educação: os movimentos sociais e a reconstrução epistemológica num contexto de colonialidade [T.N.: Research in Education: Social Movements and Epistemological Reconstruction in a Context of Coloniality.] (2012). According to these authors, in order to be consistent, this epistemology has to deconstruct the coloniality that has marked us over centuries. In the present essay, we resume a few of the arguments of Streck and Adams, and step onto this ground of epistemological de-coloniality - very slowly. We argue that there is a paradoxical mixture in the proposals of participatory research, popular education, and decolonization movements: the mixture of the copy which we already are, the anthropophagy we did to what was imposed on us. The idea of copy and repetition is presented as though in the experience of an artificer: the action of making and remaking produces the artwork and, therefore, learning. The attempt here is to think of singular ways of seeking/ producing/creating knowledge in the perspective of Latin American education.

\section{Keywords}

Coloniality - Copy - Recreation - Participatory research Popular education. 
D. Ivone Lara wrote ${ }^{1}$, and has sung, as well as many

have (and still do):

I was called on

Here I am, what's going on

I was called on

Here I am, what's going on

I came from there, I came from there when I was little

Well, I came from there when I was little

Someone told me to step on this ground very slowly

I've always been obedient, but I just couldn't help it

It was at a samba jam

that I joined the masters just to have fun

When I'm back in Bahia

I'll have a lot to tell

Oh godfather, don't be mad

I was born in samba

I just can't stop

I was called on

Here I am, what's going on

\section{"I was called on, here I am, what's going on"}

Streck and Adam's (2012) article is titled "Pesquisa em educação: os movimentos sociais e a reconstrução epistemológica num contexto de colonialidade" [T.N.: Research in Education: Social Movements and the Epistemological Reconstruction in a Context of Coloniality], and it presents this argument structure: research and education were conditioned by colonialism and, later, by coloniality. These processes produce a cultural legacy of servility that makes us Latin Americans imitators in the context of the restructuring of capitalism. In their introduction, they conclude that thought line by remembering Simón Rodríguez, based on this idea: someone who copies does not create, but tends to take wrong paths; "let us continue to imitate and take the wrong way" (RODRÍGUES, 2006, p. 202). The authors defined that colonialism is geographic domination and that once conquest is done, it produces its permanence through coloniality. Which, in turn, “[...] acts as an underlying matrix of

1- Yvonne Lara da Costa (born April 13,1921 , in Rio de Janeiro), known by her stage name Dona Ivone Lara, is a Brazilian songwriter and singer The samba song Alguém me avisou was first recorded in 1978 by Gilberto Gil, Maria Betania, and Caetano Veloso. For more information, see: http:// www.samba-choro.com.br/artistas/donaivonelara and http://www. donaivonelara.com.br/vida.php. the colonial power that has continued to exist after the independence of our countries and is now being perpetuated through the various forms of domination of the North over the South" (STRECK; ADAMS, 2012, p. 247). Based on this argument, the core of the article sits in trying to show the scene of methodological proposals that present "resistance and reaction to maintaining a cultural, epistemic matrix that we characterize as coloniality" (STRECK; ADAMS, 2012, p. 247). According to Streck and Adams, these proposals did not come out of nothing, but from emancipation movements associated, for the most part, with popular education practices.

I will divide the present text, which is no more than a counterpoint to the article of my colleagues and friends Streck and Adams, in two moments: copy as a curious controversy to the field of teaching and learning, which I title with the chorus "I came from there, I came from there when I was little"; and the "cue" their article provides me with as they argue that the methodologies proposed are "resistance and reaction", about which I affirm they did not come out of nothing, with the subheading "I've always been obedient, but I just couldn't help it”. Finally, I close the article with Dona Ivone's verses: "It was at a samba jam / That I joined the masters just to have fun". The rest of the lyrics we can sing whenever and however we like.

\section{"I came from there, I came from there when I was little"}

The concept of methodological turn (STRECK; ADAMS, 2012) comes from the pedagogical field of popular education practices and participatory research that pointed to an autonomy-oriented education, particularly since the second half of the 20th century.

Popular education in Brazil and Latin America has announced that education has a political dimension to it, and has summoned people to a political commitment. It has been present in the indigenous, agrarian, and peasant issues; problematizes gender, class, and racial/ 
ethnic violence issues; works with the health area; produces connections with popular religiosity, as well as presents popular art and culture themes, among many other issues. Its legacy is that of systematizing experiences so that ruptures and advances can take place. Among the formative questions, popular education has brought about the reading of contexts, the understanding of education as a form of political participation in transforming those contexts, and a form of preparation of leaderships. All these issues were determinant in structuring social movements. At the same time, this process caused pressures on the educational system, which, in a way, has long been teaching through copy. Tension has emerged, and still does, when people from those same movements wish to return to formal education (which often continues to insist on copy) and, once in the system, they criticize the school. As a result, new struggle spaces are reinforced which have demonstrated the need for change. And so Freire's (2000) key words, such as "dehumanizing", "changing is hard, but possible", "history as possibility rather than determination", "the limit situation", and "no one overcomes a weakness without recognizing it" (FREIRE, 2000, p. 47), become mottos with the purpose that, both in the movement and in the structure of a school, ruptures can be thought/made.

Networks as a methodological strategy are a point to be highlighted as typical of popular education. The Conselho de Educação de Adultos de América Latina - CEAAL (1982), the Rede de Educação Popular entre Mulheres - REPEM (1984), and the Rede de Educação Popular e Direitos Humanos (1984) are examples of such networks ${ }^{2}$. However, according to Oscar Jara Holliday (2006), the systematization as producer of knowledge is the methodological proposal that organizes the production of knowledge in Latin America. Still according to Holliday, it feeds several theoretical-practical renewing currents, among

2- Conceição Paludo has an article in the book organized by the United Nations Educational Scientific and Cultural Organization (UNESCO), Brazil's Ministry of Education (MEC), and CEAAL (2005) titled Educação Popular dialogando com redes Latino-Americanas (2000-2003), where the author analyzes, in various documents provided by CEALL, the importance of networks and their re-significations in the field of popular education. which are: Reconceptualized Social Work; Adult Education; Popular Communication; Theater of the Oppressed; Liberation Theology; Dependency Theory; Participatory Action Research.

According to him, systematizing allows "interpreting critically one or several experiences based on their framework and reconstruction, thus discovering or explicating the logic and the sense of the process experienced in those experiences, the several factors that intervened in that process, how they interrelate, and why they made it that way" (JARA HOLLIDAY, 2006, p. 24).

According to Streck and Adams (2012, p. 253), it is in action-research and participatory research that Latin America produces its emancipative methodological differential in the field of research:

In our view, participatory research has favorable conditions to maintain itself as a practice that contributes to strengthen the perspective of de-coloniality of power, knowledge, and being, in order to build emancipative processes. This requires recovering and rewriting, i.e., systematizing and analyzing the whole range of experiences in order to broaden the horizon of concrete possibilities, taking into account the potentials existing in those practices, and identifying in them trends of an emancipated future.

Participatory research can be defined as the methodological proposal that has built political responsibility in relation with those who are studied, i.e., a proposal aware of the importance of involving the studied community. The "findings" and their systematization should return to the group researched in the form of a dialogue.

This proposal is, in a way, a copy! Particularly when we study the traditions of qualitative research, which take us to European and North American schools, which announced, as early as in the $18^{\text {th }}$ century and throughout the $19^{\text {th }}$, according to Bernadete Gatti and Marli André (2010), and Heinz-Hermann Krüger (2010), that there were some attitudes more 
participatory and committed to interacting with the context ${ }^{3}$. Ethnomethodology, oral history, and different groups connected with researchers who generated the first qualitative research groups (action-research, collaborative research) around the world in the 20th century are important pieces to help us understand the contributions creatively structured in our America ${ }^{4}$.

It sounds rather strong to affirm that both copy and the insistence on copy maintain the error, even when copy has its meaning directed towards the historic field. Bya Braga ${ }^{5}$ (MENDONÇA, 2009, p. 7), who discusses the production and teaching process in mime Ettiene Decroux's dramatic art, questions:

Who is afraid of copy? Who fears repeating? The condition to learn mimicry is repetition, imitation in various work processes. There is nothing to fear. This is no obstacle to an artistic, performing approach that transcends the historic and canonic dramatic. What there is to be feared is, in fact, the short time to learn a trade such as this, which no longer exists in this contemporary, obscure time. Our time seems to encourage only a flying over the landscape, rather than apprehending it. In repetition is technique as creation process. Thus is Decroux's proposal for the artisanship of the actor.

I advocate this understanding of copy for pedagogy, while noting that, to some people, the idea of, and the word "copy" cause fright and repulsion. Nevertheless, I realize the argument of copy's reality and possibility. Copy is but one of the techniques in the learning process.

3- Bernadete Gatti and Marli André (2010), as well as Heinz-Hermann Krüger (2010), briefly summarize the history of qualitative methods in education, and show that it was not until the mid-1960's that they became well known in education.

4- Franco Cambi (1999, p. 25) denominates "the many historiographic orientations" that have transformed the way we understand history and the development of scientific research through renewed methodological principles. According to him, there are four orientations: (1) Marxism; (2) Annales research and total history; (3) psychoanalysis; (4) structuralism and quantitative studies. Based on these renewing orientations, Cambi argues, three revolutions occurred in historiography: one of methods, one of time and one of documents.

5- Bya Braga is the pseudonym of artist and professor Maria Beatriz Mendonça.
And technique is the work of combining hand and thought to solve a problem, a necessity that generates work and, in the artificer's hand, improvement. According to Richard Sennet's (2009) analysis, for a professional in whatever field to become qualified - i.e., to become an artificer -, it will take him no less than ten thousand hours of experience in his trade.

Is the South the creator of the innovative proposal of autonomy through participatory research? Or could it be that the South, having been colonized, was led to copy - and copy it did - then vomited this content in another way, within another context? It copied and copied, and now, behold, we have something different, particularly an attitude of returning it as a field of power and struggle so that research can be committed to changes for the people who "suffer" the research.

That Latin America is intertwined with the historical determinants of colonialism and, later, of coloniality, is a fact. However, that this should produce and perpetuate the culture of servility - making us "imitators in the context of the productive restructuring of capitalism, since 'someone who copies does not create, but tends to take wrong paths" - seems to me to overly dichotomize this aspect, say primitive, of pedagogy. A primitive pedagogical aspect indeed, for when we learn at our most originary/ initial degrees, do we not start by copying/ imitating? Is the transmission of knowledge not a kind of teaching of what already exists, therefore a copy? We need to ask ourselves about this and think: to what extent do we copy to keep ourselves servile or, on the other hand - and ambiguously - do we copy in order to survive and then, a little later, get rid of the copy to "recreate" other paths?

We can affirm that, in Latin America, social movements have supported [some have clung, and maybe still do, to] methodological processes that initially "copied" knowledge from the North, but such movements developed a criticism and produced Liberation Theology and Popular Education, as argued by Brandão (2002) and Faustino Teixeira (2006). At the same 
time, we had, during the 19th and early 20th centuries, a process of criticism of positivist studies and research, and that generated other paths which were resumed in the post-war period through autobiographical studies, oral history, ethnographies, feminist and genders studies, etc. By criticizing Streck and Adams (2012), I intend to introduce the debate regarding the importance of rereadings and influences of the North that are not necessarily colonizing, particularly in terms of the "anthropophagy" so well illustrated by Oswald de Andrade in his Manifesto (1928, 1976). To me, this seems to make us think of a movement among peers, by means of a more face-to-face relationship for producing the methodological turn, even though we know the abyss between the colonies themselves (e.g., the difference of language in Brazil's relationship with other Latin American countries) and between them and the North.

Among such proposals are actionresearch (BARBIER, 2002; THIOLLENT, 1986), life stories (JOSSO, 1999, 2004; NÓVOA, 1992), feminist studies with an emphasis on the aspect life experience for women's history visibility (PERROT, 2007; RUTHER, 1993; EGGERT, SILVA, 2011), discussion groups (WELLER, 2006; GASKELL, 2002; MEINERZ, 2011), and the documentary method (BOHNSACK, 2003). In their wide range of shades, all of these proposals were somehow copied and have different variations and recreations in the research of education and humanities in general, both in Brazil and other parts of Latin America. These methodological matrices are present in participatory research (BRANDÃO; STRECK, 2006), and there is an intercontinental network of sorts that stimulates interesting copies which have been allowing rereadings, recreations, and creations - why not?

To the methodological turn indicated by Streck and Adams (2012) I add the notion that this turn is only possible when we understand the dimension of the marks of the copies and dialogues that occurred between the diverse methodological experiences that crossed continents and mixed together. The methodological turn implies the consciousness of that mixture.

\section{“I've always been obedient, but I just couldn't help it”}

Miguel Arroyo (2012, p. 29-45) affirms that "social movements force us to tell history in another way". According to him, it is necessary to "[...] understand the radicality of social movements - they are not 'beggars'. They are collectives that contest, deconstruct order." Still according to Arroyo, they bring up the question that makes the maintenance of dualist curricula uncomfortable. This radicality, he argues, produces theory that is based on social movements. He mentions the feminist movement as one of the movements that most produces theory ${ }^{6}$. This movement has made some people uncomfortable as it insists in making visible the issues of gender violence, of silencing about women's life and work throughout history. The movement first organized itself within certain social groups and classes involved in the suffragism and abolitionism; then, in the Marxist groups, denouncements emerged about poor labor conditions, to widen out in a debate conducted by women from Africa and Latin America, who questioned whiteness and the North as references. African, Asian, and South American feminist women indicated the colonialism of northern feminists. (ROSEMBERG; MOURA; SILVA, 2009). Sexisms and racisms have been - and still are - denouncements that emerged with the feminist and the black movements produced in the 20th century.

Over the history of Brazilian education, we can affirm that social movements have produced a deep questioning for education in general, and in a very singular way, for the school. In this case, school education may not want to face the questions posed, however, it

6- Miguel Arroyo made this affirmation during a seminar presentation we shared at the Encontro de Educação Popular e Formação Docente at the Universidade Estadual do Rio de Janeiro (UERJ), in São Gonçalo, on August 28, 2011. The text of that presentation was later published in 2012. 
suffers substantial consequences in its everyday life in relation to the movements. When Brazilian black male and female slaves were set free, they joined the school through the backdoor; but they gradually established collective struggles that produced what we now see, i.e., the debate and achievement of visibility for the contents historically neglected by society concerning the history of Afro-Brazilian culture through the Law 10,639/037. According to Fúlvia Rosemberg, Chirley Bazilli, and Paulo Vinicius Baptista da Silva (2003), the black movement established the necessary tension so there could be an agenda that reflected on both popular education and the school.

It is in the context of social movements like the ones mentioned above that we can understand popular education. It was through popular education that, over forty years ago (BRANDÃO, 2002), we could see a pedagogical legacy being produced that discussed educative processes different than those implemented in the banking education (FREIRE, 2002) brought from overseas into our Latin American colonized experience.

Popular education was understood as something produced out of the school, which tensions school education. Paulo Freire was no doubt a key person to this debate in Brazil. According to Danilo Streck (2006, p. 541), "with the pedagogy of the oppressed, there is a new look at the pedagogical practices present in social processes, and at social processes themselves as pedagogical mediations in the construction of new knowledge and new practices." Today, after so many years of struggle for quality public school education, we are still hopeful and see many things happening. By no means do we have the feeling of mission accomplished. We know we live in a different time than that when voting was only for white, male, literate landowners. We live in the time of democracy, in which distance grows from the

7- Law 11,645, of March 2008, in turn, modifies Law 10,639, of January 9, 2003, and establishes the guidelines and bases of national education, thus including in the official curriculum the Afro-Brazilian and Indigenous History and Culture as mandatory themes. memories of military dictatorship, when people who did not agree with the regime lived in fear, clandestinity, persecution, and death. We live in a time when governments established in Latin America are formed by people and groups who had been in the resistance and/or had integrated certain social movements, and who, to some extent, produced popular education, i.e., the experience of pedagogical processes oriented to the citizenship of those who were struggling and wanted to learn and teach in another way than that of the traditional, authoritarian school. In a way, we have been able to see that not all the school offered was authoritarian, and that the legacy of knowledge already produced needs to be transferred. People who come from popular education also realize that there is a legacy to be remembered which is a production of knowledge already verified, that such knowledge must be translated in one way or another so that the new generations can get to know and recognize what is undeniably already there.

Based on this context, I believe that, over the journey, particularly over the last fifty years, we have seen a way being trod by experiences that foment, both in Brazil and the rest of Latin America, the mark of many feet: from the boots of the military to the resistance and boldness of a wide range of groups and movements. Among these, I rely on two: the feminist movement and popular education. The former, occurring across Latin America, stands out among other worldwide feminist movements due to its resistance to military dictatorship; as to the latter, it stands out by the mixture it produces between Marxists and Christians, through the basic ecclesial movements, which were nurtured by Liberation Theology and the Pedagogy of the Oppressed.

There is something else beyond denouncement and announcement, which happens when we meet anywhere and, also in this case, when we conduct research and make comparisons, we realize similarities and differences. The proposal of a non-colonial epistemology emerges, in a way, because there 
was someone from the metropolis who said we were bright! We had gold! It is thus that I recall situations of persons from the South who went North to study and, as they arrived there, were warmly welcomed, and eventually built affective and political bonds. I remember professors who received many Latin American students - many of whom were exiled from military dictatorships - and, as they interchanged their knowledge, many of these professors came to the South in order to learn more about what their students spoke so much of. One such example is Gustavo Gutiérrez, as he recounts how he met, in 1988, Father Gerhard Ludwig Müller, now Archbishop and prefect at the Congregation for the Doctrine of the Faith, in Rome ${ }^{8}$. Father Josef Sayer ${ }^{9}$ had invited Gutiérrez to participate in a course he had organized for a group of German professors in a seminar um Munich. Professor Müller, who was then teaching dogmatic theology, said to Gutiérrez, at the end of the meeting, "that the discussion had reminded him of the importance of practice, therefore he proposed to come periodically to Peru to help as a professor. During 15 years, he spent three to four weeks of his annual holidays teaching at the Cuzco seminar" (GUTIÉRREZ, 2013). Therefore, the pursuit of experience in everyday reality brought Müller to Peru, to get to know "this ground very slowly", and he joined the jam.

We had scholar partners, advisors who taught and learned through classes and through the advising of theses that demonstrate/prove the dialogue with those from the South. As with Müller and Sayer, people like Ivone Gebara's advisor, Adolf Gesché, made all the difference in the education of Latin Americans in the field of theology. Gesché foreworded Gebara's book, Rompendo o silêncio, and, according to him, Gebara "let the 'thing' itself speak, in its own intentionality, its own phenomenality, and not in an extraneous representation" (GESCHÉ, 2000, p. 22). Such "extraneous representation" was the

8- See the IHU electronic journal, on http://www.ihu.unisinos.br/ noticias/524471-gigante-da-teologia-entrevista-com-gustavo-gutierrez.

9- Josef Sayer was a missionary in Lima, and later held the position of director at MISEREOR (a catholic organization that supports development) from 1997 to 2013. same one identified and recognized by theologian Ernesto Balducci in a congress in Florence 1984, cited by Faustino Teixeira (2006, p. 29):

Theologians in those countries live among the people more than in libraries, they must hide from the police, they have known prison and torture, and they have seen with their own eyes the blood shed for the love of human beings. [...] It is definitely by their merit [we would say now, in 2012, by their pain] that, here today, we are people of hope.

Likewise, the ruptures that feminists carried out were also an effect of the debate and the dialogue they had among themselves and with men who were restless and open to the changes that signaled their emergence then, and still do now. It is hardly necessary to remember Freire, for he divulged in many of his works how, as he read and dialogued with people from the so-called colonizer North, he was recognized and even embraced by them. It is in this context that I present the argument of complicity between North and South to be debated, which is, in my view, a consequence of the systematization and mixture of experiences among groups that possessed some syntony and thus produced produce new knowledge. Such knowledge is produced at dialogues wherever movements occur, and they occur simultaneously, both in the North and the South.

\section{“'lt was at a samba jam that I joined the masters just to have fun"}

One question emerges from the questioning we have conducted: is it possible to decolonize based only on ourselves? What instruments do we use so that decolonization can take place?

We have looked closely into the methodological turn, understanding that we do find copy in it, but that it is possible to do things differently. Therefore, like Streck and Adams 
(2012), we highlight the importance of social movements and add feminism and the black movement. There is a conspiring ambiguity that makes the how happen. The ammunition that causes us to be "the masters" is produced in an complex net of knowledge already posited, which can be reused whether for maintaining domination or not. Simón Rodriguez (17711845), tutor of Simón Bolívar, had “[...] received influence of the thinkers of European modernity [...]". (STRECK and ADAMS, 2012, p. 250). Rodriguez was creative in developing for his "educators" a proposal of Latin American popular education.

Differently put, the production of modernity provided elements that allowed dominated/colonized groups to overcome the barrier of individual struggles for freedom and autonomy over the centuries. A classic case is the history of women who, silenced by death or confinement in asylums or their own homes, created, in the 19th century, the foundations of a collective, democratic, instrumentalized, and organized struggle. This was only possible in a context of strikes and factory workers' movements based on arguments built within modern reason, which were the stature of a Karl Marx, Friedrich Engels, Rosa Luxemburg, Clara Zetkin, among so many other people committed to the dignity of life.

Therefore, the qualitative research experimented in various forms has, in our continent, the seasoning of political commitment to social change, but we are not the only ones! The "life worlds" that Wivian Weller (2002; 2003) highlight based on Karl Mannheim's ideas about "worldview" (MANNHEIM, 1980, p. 101, apud WELLER, 2003, p. 2) are "a series of experiences connected to a same structure, which, in turn, constitutes a common foundation of experiences that pervade the life of multiple individuals. This concept, I suspect, Freire read in some text by Mannheim and then called it a "world reading".

In this perspective, "nobody reads the world isolatedly" (PASSOS, 2008, p. 241), as there are "as many worlds as possible readings of it" (PASSOS, 2008, p. 242). By means of the researcher's thorough, systematic reading, significant support is secured for proceeding with the processes of consolidation and emancipation of the various social groups which are already protagonists in these processes.

In our view, discussion groups are close to the circles of culture and talking circles described by Paulo Freire. According to Brandão (2008), as Freire questions the banking way of educating, he proposes circles of culture where people can share, in a circle of people, their experiences and knowledge. Thus, no one visibly occupies a prominent place. Consequently, "dialogue is no longer a simple methodology or a group action technique, it becomes the guideline itself [...]" (BRANDÃO, 2008, p. 77). This is one case where we can draw a parallel between something that was happening in Brazil and the rest of Latin America in the 1960's and 1970's and what was happening in the United States in the years after World War II. Discussion groups emerged in social empirical research conducted by members of the Frankfurt School since the 1950's: “they constitute an important tool to reconstruct the social contexts and models that guide subjects' actions" (WELLER, 2006, p. 246). This occurs because these groups "represent an instrument through which the researcher establishes a path that allows reconstructing the various social environments and the collective habitus of the group" (WELLER, 2006, p. 247).

I highlight a very significant occasion experienced at a scientific event organized by professor Wivian Weller (Universidade de Brasília) in March 2010, through her research group, Gênero e Juventude (GERAJU). At this seminar, we had the participation of a German group experienced in the process of documentary method in which professor Ralf Bonhsack himself was present. At one point of the exchanges and debates on the methods and research presented, I asked professor Bohnsack ${ }^{10}$ how they proceeded in order to eventually return

10- The researcher participated in the I Simpósio Brasileiro-Alemão de Pesquisa Qualitativa e Interpretação de Dados. 
the systematization of data collected among the groups researched. This question caused a feeling of strangeness in the German group, since this was not a question to them, i.e., the return occurs in the form of scientific articles. Those involved, if they wish to have access to the material, have the same access as anyone does, by means of scientific publications, which are public. Since that dialogue, it was possible to observe better one of the things that distinguish us - methodologically, that is. Something that does not make us any better or worse, but different. The reality in our world, where most people do not read, or have access to, let alone the habit of reading, scientific journals/papers, puts us in face of other ways of thinking our scientific work. The reality of our context, i.e., that of more precarious worlds, is that - through participatory research with groups that accept and experience being researched respectfully and with the commitment of being recognized as persons with faces - we are able to produce a science with a different face. In this perspective, producing a theoretical tradition in the field of participatory research is still a challenge, since the richness of methodological diversity is fragmented, when face to face we seek the exchange/dialogue of knowledge ${ }^{11}$.

\section{Concluding staccatos or "Oh godfather, don't be mad"}

The view of the European experience with the Latin American view, or with a view from anywhere else, once recognized and properly systematized, can trigger decolonization; likewise, they can influence readings tensioned between school and non-school spaces, and between the legacy already produced by the mostly androcentric academy and the production of the feminist movement and black movements. What we proposed to put forth as a provocation, based on Streck and Adams'

11- In this context, the ethics committees of each university expressed their positions. About these themes in research of education, it is worth mentioning the 36. ${ }^{a}$ Reunião Nacional ANPEd, where a table with debates was held at the Universidade Federal de Goiás, whose proceedings were published in the journal Práxis Educativa, v. 9, n. 1, 2014.
(2012) article, is that there is a thin line between what was imposed on us as a colonized people and what we returned recreated, regurgitated, or deconstructed-reconstructed. It is interesting for this line of thought to be exposed, for the sake of our own humbleness and survival!

Ivone Gebara (2000, p. 45) emphasizes that feminist scientists from both North and South have systematically denounced the historical and cultural inequality that women experience to a greater degree than men, and that black women have been living in the most disgraceful levels of inequality. Learning to say that we technically perceive other shades is tensioning, is enabling tension and proposing the debate. Otherwise, we have what Brandão calls "the unadmitted ignorance about the reality of the other" (1986, p. 13) and, by not admitting that we ignore (humbleness), we risk authorizing ourselves to perceive the other “[...] as I want to, in order to intervene over him, transforming him according to the image and horizon that my good conscience has drawn for him in advance, through my work" (BRANDÃO, 1986, p. 14). Brandão incites and prompts us to dialogue with the idea of coloniality in the act of researching. I suspect he writes such things because he was close to Paulo Freire, who wrote a classic article arguing that we have to maintain this tensioning. I refer to the chapter that opens Brandão's first book about participatory research (1981), titled Criando métodos de pesquisa alternativa: aprendendo a fazê-la melhor através da ação [T.N.: "Creating methods of alternative research: learning to do it better through action".].

Our hope is to achieve an ever-greater notion of the unadmitted ignorance of the reality of the other, which can generate a creative reaction and which, in the Latin American case, has already demonstrated its power in proposals like Liberation Theology and Popular Education. It is important for us to have this memory, even though the weakening of our resistances is now visible and we seem demobilized even in the social movements themselves. However, we still have the legacy of a methodological production which 
can be better studied, founded, and presented in its conceptual authenticity. The methodological conceptions produced until today in so many different forms constitute a challenge to the science produced in the South. We can more and more do what women's movements have warned regarding their need to study themselves more. The possibility of admiration, not like some male or female Narcissus, but rather in a perspective of integration with the political movement in order to lead us to actually read ourselves and, therefore, recognize ourselves more. We can think, for example, that through the actions of groups like the Associação das Mulheres Brasileiras (AMB), Marcha Mundial das Mulheres, Movimento Nacional de Mulheres Agricultoras, Movimento dos Trabalhadores Rurais Sem Terra (MST) das Mulheres, we have an intersection of social movements that can produce knowledge that circulates in different social environments. And, in different ways, we can speak about the multiplicity of such knowledge.

When social movements establish that their knowledge is valid, and that it is mixed not only as a survival strategy, but as an argument of struggle and knowledge, they can come out of their grottos and become a manifestation of authorship. The conscious methodological mixture can be a vital strength in this process. Perhaps the idea of "stepping on this ground very slowly" contains this cautious, yet bold pressure so that the academy finds itself more and more pressed into engaging in SouthSouth, South-North, South-North-South and North-South-North dialogues.

As I consider whether it is possible to decolonize based on ourselves, I have an ambiguous feeling: if, on the one hand, it seems we can, on the other hand, I can see the fragility of the instruments used, of the "copies" that are always and still in process to cause knowledge production to take place. And I can see something else: that we depend on partnerships and complicities from any part of the world. And, in this case, we should ask: in the Latin American ground, does the fact that we are aware of the incorporation of coloniality - which, as I pointed in the beginning of the article, based on Streck and Adams (2012), acts as an underlying matrix of the colonial power contribute for other South-North, South-South dialogues to take place?

\section{References}

ANDRADE, Oswald de. 0 manifesto antropófago. In: TELES, Gilberto Mendonça. Vanguarda européia e modernismo brasileiro: apresentação e crítica dos principais manifestos vanguardistas. 3. ed. Petrópolis: Vozes; Brasília, DF: INL, 1976.

ARROYO, Miguel. Os movimentos sociais reeducam a educaçao. In.: ALVARENGA, Marcia Soares de (Org.). Educação popular, movimentos sociais e formação de professores: outras questões, outros diálogos. v. 1. 1. ed. Rio de Janeiro: EdUERJ, 2012. p. 29 -45.

BARBIER, René. A pesquisa-ação. Tradução Lucie Didio. Brasília, DF: Plano, 2002.

BOHNSACK, Ralf. Rekonstruktive Sozialforschung: einfürung in qualitative methoden. Leske-Budrich: Oplade, 2003.

BRANDÃO, Carlos Rodrigues. A educação popular na escola cidadã. Petrópolis: Vozes, 2002.

BRANDÃO, Carlos Rodrigues. Círculos de cultura. In: STRECK, Danilo R.; REDIN, Euclides; ZITKOSKI, Jaime José. Dicionário Paulo Freire. Belo Horizonte: Autêntica, 2008. p. 76-78.

BRANDÃO, Carlos Rodrigues. 0 ardil da ordem. Campinas: Papirus, 1986.

BRANDÃO, Carlos Rodrigues; STRECK, Danilo R. Pesquisa participante: 0 saber da partilha. Aparecida: Ideias e Letras, 2006.

CAMBI, Franco. História da pedagogia. São Paulo: Unesp, 1999.

CASTAGNARO, Mauro. Gigante da teologia: entrevista com Gustavo Gutiérrez, 8/10/2013. São Leopoldo: IHU, 2013. Disponível em: <http://www. ihu.unisinos.br/noticias/524471-gigante-da-teologia-entrevista-com-gustavo-gutierrez>. Acesso em: 3 mar. 2014.

EGGERT, Edla; SILVA, Marcia Alves da. Observações sobre pesquisa autobiográfica na perspectiva da educação popular nos estudos de gênero. Revista Contexto \& Educação, ljuí, v. 26, n. 85, p. 51-68, jan./jun. 2011.

FREIRE, Paulo. Pedagogia da autonomia: saberes necessários à prática educativa. 25. ed. São Paulo: Paz e Terra, 2002.

FREIRE, Paulo. Pedagogia da indignação: cartas pedagógicas e outros escritos. São Paulo: Edusp, 2000. 
FREIRE, Paulo. Criando métodos de pesquisa alternativa: aprendendo a fazê-la melhor através da ação. In: BRANDÃo, Carlos Rodrigues. Pesquisa participante. São Paulo: Brasiliense, 1981. p. 34-41.

GASKELL, George. Entrevistas individuais e grupais. In: BAUER, Martin W.; GASKELL, George. Pesquisa qualitativa com texto, imagem e som: um manual prático. 5. ed. Petrópolis: Vozes, 2002. p. 64-89.

GATTI, Bernadete; ANDRÉ, Marli. A relevância dos métodos de pesquisa qualitativa em educação no Brasil. In: WELLER, Wivian; PFAFF, Nicolle. Metodologias da pesquisa qualitativa em Educação. Petrópolis: Vozes, 2010. p. 29-38.

GEBARA, Ivone. Rompendo o silêncio: uma fenomenologia feminista do mal. Tradução Lúcia Mathilde. Petrópolis: Vozes, 2000.

GUESCHÉ, Adolf. Apresentação. In: GEBARA, Ivone. Rompendo o silêncio: uma fenomenologia feminista do mal. Petrópolis: Vozes, 2000. p. 7-9.

HOLLIDAY, Oscar Jara. Para sistematizar experiências. Tradução Maria Viviana V. Resende. 2. ed. Brasília, DF: MMA, 2006. (Monitoramento e avaliação, 2).

KRÜGER, Heinz-Hermann. A relevância dos métodos de pesquisa qualitativa em Educação na Alemanha. In: WELLER, Wivian; PFAFF, Nicolle. Metodologias da pesquisa qualitativa em educação. Petrópolis: Vozes, 2010. p. 39-52.

MEINERZ, Carla Beatriz. Grupos de discussão: uma opção metodológica na pesquisa em educação. Educação e Realidade, Porto Alegre, v. 36, n. 2, p. 485-504, maio/ago. 2011. Disponível em: <http://www.ufrgs.br/edu_realidade>. Acesso em: 3 abr. 2012.

MENDONÇA, Maria Beatriz (Bya Braga). Étienne decroux e a artesania do ator. Rio de Janeiro: Portal Unirio, 2009. Disponível em: <http://www.seer. unirio.br/index.php/pesqcenicas/article/viewFile/710/650>. Acesso em: 29 mar. 2014.

NÓVOA, Antonio (Org.). Vida de professores. Porto: Porto, 1992.

PALUDO, Conceição. Educação popular - dialogando com redes latino-americanas (2000-2003). In: (Org.). PONTUAL, Pedro; IRELAND, Timothy. Educação popular na América Latina: desafios e perspectivas. Brasília, DF: UNESCO; MEC; CEAAL, 2005. p. 41-66.

PASSOS, Luiz Augusto. Leitura do mundo. In: STRECK, Danilo R.; REDIN, Euclides; ZITKOSKI, Jaime José. Dicionário Paulo Freire. Belo Horizonte: Autêntica, 2008. p. 240-242.

PERROT, Michelle. Minha história sobre as mulheres. São Paulo: Contexto, 2007.

ROSEMBERG, Fúlvia; MOURA, Neide Cardoso de; SILVA, Paulo Vinicius Baptista da. Combate ao sexismo em livros didáticos: construção da agenda e sua crítica. Cadernos de Pesquisa, São Paulo, v. 39, n. 137, p. 489-519, 2009.

ROSEMBERG, Fúlvia; SILVA, Paulo Vinícius Batista da; BAZILLI, Chirley. Racismo em livros didáticos brasileiros e seu combate: uma revisão de literatura. Educação e Pesquisa, São Paulo, v. 29, n. 1, p. 125-146, 2003.

RUTHER, Rosemary. Sexismos e religião. São Leopoldo: Sinodal, 1993.

STRECK, Danilo R. Da pedagogia do oprimido às pedagogias da exclusão: um breve balanço crítico. Educação e Sociedade, Campinas, v. 30, n. 107, p. 539-560, maio/ago. 2009

STRECK, Danilo R.; ADAMS, Telmo. Pesquisa em educação: os movimentos sociais e a reconstrução epistemológica num contexto de colonialidade. Educação e Pesquisa, São Paulo, v. 38, n. 1, p. 243-258, 2012.

TEIXEIRA, Faustino. Teologia da libertação: eixos e desafios. In: Centro de Estudos Bíblicos - CEBI. Teologia da libertação e educação popular a caminho. São Leopoldo: CEBI, 2006. p. 27-65.

WELLER, Wivian. Grupos de discussão na pesquisa com adolescentes e jovens: aportes teórico-metodológicos e análise de uma experiência com o método. Educação e Pesquisa, São Paulo, v. 32, n. 2, p. 241-260, maio/ago. 2006.

WELLER, Wivian. "Hip hop" em São Paulo e Berlim: orientações político-culturais de jovens negros e jovens de origem turca. In: SEMINÁRIO INTERNACIONAL EDUCAÇÃO INTERCULTURAL, GÊNERO E MOVIMENTOS SOCIAIS: identidade, diferenças e mediações, 2., 2003, Florianópolis. Anais... Florianópolis: [s. n.], 2003. 1 CD.

WELLER, Wivian; BOHNSACK, Ralf. Karl Mannheim e o método documentário de interpretação: uma forma de análise das visões de mundo. Estado e Sociedade, Brasília, DF, v. 17, n. 2, p. 375-396, jul./dez. 2002. [Inovações no campo da metodologia das ciências sociais].

Received on May 27th 2014

Approved on October 21st, 2014

Edla Eggert is a professor at the post-graduation program in education at the Universidade do Vale do Rio Sinos (UNISINOS) and a CNPq-supported researcher. 